\title{
Letramentos para o trabalho nos livros didáticos para 0 Ensino Fundamental II da Educação de Jovens e Adultos (EJA)
}

\author{
Márcia Rodrigues de Souza Mendonça (PQ), Beatriz M. da Silva (IC).
}

\section{Resumo}

Este projeto propõe analisar as coleções Caminhar e Transformar e Coleção Viver, Aprender - segundo segmento do Ensino Fundamental para a Educação de Jovens e Adultos (EJA) -, focando o ensino de Língua Portuguesa e os gêneros do discurso que auxiliem teoricamente o letramento profissional.

Palavras Chave: letramento, mundo do trabalho, EJA.

\section{Introdução}

O tema letramento no trabalho é ainda pouco explorado no Brasil. Assim, é pertinente para a Linguística Aplicada investigar se os materiais didáticos trazem a teoria voltada para 0 letramento profissional, que permita 0 desenvolvimento de habilidades necessárias para que os alunos se insiram nas práticas de letramento do mundo do trabalho. Dessa forma, conceitos como o de Mendonça (2013) letramentos profissionais - e o de Bazerman (2006) - gêneros textuais - são essenciais para o estudo desta pesquisa, que consiste na análise dos gêneros textuais presentes em duas coleções didáticas referentes aos anos finais do Ensino Fundamental para a Educação de Jovens e Adultos (EJA) - Caminhar e Transformar e Viver, Aprender -, focando o ensino de Língua Portuguesa, especificamente as habilidades de leitura e escrita.

\section{Resultados e Discussão}

As coleções dos anos finais do Ensino Fundamental da EJA analisadas na pesquisa foram as Viver, Aprender e Caminhar e Transformar. Os gêneros encontrados nas coleções estão elencados nas tabelas a seguir.

Tabela 1. Coleção Viver, Aprender

\begin{tabular}{|c|c|c|c|c|}
\hline Volume & \multicolumn{4}{|c|}{ Gêneros trabalhados no volume } \\
\hline & Cap.1 & Cap. 2 & Cap. 3 & Cap. 4 \\
\hline V. $1: 6^{\circ}$ ano & $\begin{array}{l}\text { Narração, noticia, } \\
\text { divulgaçẫo } \\
\text { cientifica. }\end{array}$ & Poema. & $\begin{array}{l}\text { Artigo de divulgação } \\
\text { científica. }\end{array}$ & $\begin{array}{l}\text { Como } \\
\text { jornal. }\end{array}$ \\
\hline V. $2: 7^{\circ}$ ano & O que é género? & Conto. & \begin{tabular}{|l} 
Verbetes. \\
\end{tabular} & Notícia. \\
\hline V. $3: 8^{\circ}$ ano & $\begin{array}{l}\text { Estratégias } \\
\text { leitura. }\end{array}$ & $\begin{array}{l}\text { Poesia, } \\
\text { poemas. }\end{array}$ & $\begin{array}{l}\text { Como pesquisar - } \\
\text { resumo. }\end{array}$ & $\begin{array}{l}\text { Noticia e e } \\
\text { reportagem. }\end{array}$ \\
\hline V. $4:$ & $\begin{array}{l}\text { Coesẫo } \\
\text { coerência. }\end{array}$ & Crônica. & $\begin{array}{l}\text { Artigo de opiniấo - } \\
\text { argumentação. }\end{array}$ & Editorial. \\
\hline
\end{tabular}

Tabela 2. Caminhar e Transformar

\begin{tabular}{|c|c|c|c|c|}
\hline Unidade & \multicolumn{4}{|c|}{ Gêneros trabalhados na unidade } \\
\hline - & Cap. 1 & Cap. 2 & Cap. 3 & Cap. 4 \\
\hline $\begin{array}{l}\text { U. 1: Iguais } \\
\text { e diferentes }\end{array}$ & Carta & Cordel em versos & $\begin{array}{l}\begin{array}{l}\text { Autobiografia } \\
\text { biografia }\end{array} \\
\end{array}$ & Mito/narração \\
\hline $\begin{array}{l}\text { U. 2: Aqui é } \\
\text { o meu lugar }\end{array}$ & $\begin{array}{l}\text { Crônica } \\
\text { narrativa }\end{array}$ & Conto & Poema & Propaganda \\
\hline $\begin{array}{l}\text { U. } \\
\text { Trabalho e } \\
\text { transformaç } \\
\text { ão }\end{array}$ & Charge e tirinha & Paródia & Currículo & Debate \\
\hline $\begin{array}{l}\text { U. 4: Mundo } \\
\text { cidadão }\end{array}$ & Seminário & Entrevista & Reportagem & $\begin{array}{l}\text { Artigo } \\
\text { opinião }\end{array}$ \\
\hline
\end{tabular}

É possível observar que alguns gêneros aparecem nas duas coleções. Exemplo: conto, poesia, reportagem. Pode-se notar também que há uma variedade de gêneros dentro das coleções que permitem, direta ou indiretamente, o desenvolvimento de habilidades que podem ser aproveitadas no mundo do trabalho. Exemplo: resumo, carta, seminário, entrevista, currículo, debate. Dessa forma, o professor da EJA tem a importante função de explorar nesses gêneros as habilidades necessárias interligadas às práticas sociais de leitura e escrita presente nos contextos do mundo do trabalho.

\section{Conclusões}

O estudo de gêneros é fundamental ao letramento profissional, para entender as concepções de letramento localmente elaboradas, e as práticas de leitura e escrita relevantes para o mundo do trabalho, bem como a explorar a capacidade de produzir os discursos - orais, escritos, e multimodais - necessários em contextos de trabalho, levando em consideração que os gêneros presentes nesses contextos são bem diversificados.

\section{Agradecimentos}

Agradeço o amor dos meus pais e do meu namorado, que sempre me incentivaram a nunca desistir dos meus objetivos; às minhas amigas, Annelise e Rafaela, pelo companheirismo e amizade; à Prof. a Márcia Mendonça, pela paciência e simpatia de sempre, e ao CNPq por proporcionar esta oportunidade de pesquisa.

BAZERMAN, C. Atos de Fala, Gêneros Textuais e Sistemas de Atividades: como os textos organizam atividades e pessoas. In Gêneros textuais, tipificação e interação. DIONISIO, A. P., et. al. (Org.). 2 ed. São Paulo: Cortez, 2006. Pp. 19-46.

MENDONÇA, M. Letramentos no mundo do trabalho. Universidade Estadual de Campinas, 2013. 